\title{
Types of Question and Questioning Tactics Used by The Teacher of Children 3 A Class
}

\author{
Chelinedyon Tella \\ English Department, Faculty of Letters, Petra Christian University \\ Siwalankerto 121-131, Surabaya, East Java, INDONESIA \\ E-mail: cheline.tella@yahoo.com
}

\begin{abstract}
Questioning is one of the most important classroom activities. This study is conducted to find out the/ types of question and questioning tactics used by the teacher of Children 3A class at Petra Language Center (PLC). The theory used was from Wragg and Brown (2001). The data were all the questions asked by the teacher during the class meetings related to the lesson taken from two meetings, each lasted in 60 minutes. I used classroom observation as the instrument to collect my data. From the study, out of the three common types of questions, I found out that only two types of questions were used, i.e conceptual and empirical question. Meanwhile, only six questioning tactics were used, i.e structuring, directing and distributing, pitching and putting clearly, pausing and pacing, listening to replies and responding and sequencing. I concluded that the teacher of Children $3 \mathrm{~A}$ class asked different types of question and used various questioning tactics to check students understanding by asking the meanings and definitions since students are in the beginner level, thus giving equal opportunities to every students to answer questions.

Keywords: Teacher's Question, Types of Question, Questioning Tactics
\end{abstract}

\section{INTRODUCTION}

Teacher and students interact all the time in the classroom. The interaction involves "all communication which refers not only to those exchanges involving authentic communication but to every oral exchange that occurs in the classroom" (Ellis, 1990, p. 12), which also includes asking questions and giving answer.

Questioning is one of the most common activities done in the classroom. During the teaching and learning process inside the classroom, there are times when teachers are required to present lectures; and there are times when they are expected to give students questions in order to "arouse interest and curiosity concerning a topic; to focus attention on a particular issue or concept; to develop an active approach to learning; to stimulate pupils to ask questions of themselves and others" Turney et al. (1973) as cited by Wragg and Brown (2001, pp. 7). Questions asked by teacher have many functions such as "focusing attention, exerting disciplinary control, getting feedback and most important of all, encouraging students to participate" (Farahian and Rezaee, 2012) which is why Brock (1986), Gall, (1970), Wu, (1993) consider questioning as one of the most useful activities in teaching and a method of involving students in a lesson to get students' participation. Not only to get the students to actively participate more in the classroom, Teacher's questions also help to "achieve students' communicative competence" (Kramsch, 1986).

In asking questions, teachers use different types of questions based on the function and purposes in which Wragg and Brown (2001) classified into three which are conceptual, empirical and value questions. The teacher just has to use certain question types to get student participate more in the teaching and learning process. To get students participation and more complex answer, teachers can also use seven key tactics in asking questions as Wragg and Brown (2001) has mentioned which are structuring, pitching and putting clearly, directing and distributing, pausing and pacing, prompting and probing, listening to replies and responding and sequencing. From the types of question and 
questioning tactics mentioned above, for this study, I want to find out which types of question and questioning tactics used by a teacher in a classroom to get students into participating in class.

This study is intended to find out what types of questions used by the teacher of Children $3 \mathrm{~A}$ class at PLC. Also, I want to find out the questioning tactics used by the teacher in two class meetings.

\section{Types of Question}

According to Wragg and Brown (2001, p. 1), "everyday teachers ask dozens, even hundreds of questions" for various reasons. Some of which are "encouraging thought, checking understanding, gaining attention, revision and management." (p. 8). In questioning students, the teacher uses different types of questions with the various functions. Wragg and Brown (2001) classify the types of questions into three namely conceptual question, empirical question and value question.

\section{Conceptual Question}

"Conceptual questions concerned with eliciting ideas, definitions, and reasoning in the subject being studied" (Wragg and Brown, 2001, p. 16). According to Wragg and Brown (2001), conceptual questions will help students in forming a concept. The example of conceptual questions is asking students questions like, "Why have you put cats and dogs in the same category?' or, 'What do you call animals with and without bones?'” (p. 17).

\section{Empirical Question}

"Empirical questions requiring answers based on facts or on experimental findings" (Wragg and Brown, 2001, p. 16). "Empirical types of questions involve observation, recall of facts and possible experimentation. If the reasoning is used, it is to confirm the facts or to show the connections between the facts and observations" (p. 17).

\section{Value Question}

"Value questions investigating relative worth and merit, moral and environmental issues" (Wragg and Brown, 2001, p. 17). According to Wragg and Brown (2001), value questions include morals, social concerns, health and environmental issues. The examples of value questions are "'Why do you say he's poor? - what makes you have that impression?' and 'Now, why do you think people might drink methylated spirits? Why do they sit around in the park all day - James?"” (p. 19)

\section{Questioning Tactics}

Wragg and Brown (2001) explain that to receive good answers from students, it is also important to think of the tactics used in asking questions to decrease teachers' and students' errors. Some of the errors are "asking too many questions at once, asking a difficult question too early in the sequence of events and not giving pupils the time to think" (Wragg and Brown, 2001, p. 28). The seven key tactics used by teachers in questioning students are as follows.

\section{Structuring (Signposting)}

"Structuring consists of providing signposts for the sequence of questions and the topic. The structuring may be a brief exposition of the topic, a review of a series of questions and explanations based on a previous lesson or a statement" (Wragg and Brown, 2001, p. 29). French and Maclure (1983) describe structuring as 'orientations' to construct students "previous knowledge" and "experience." The example of structuring is "The air presses againts the side of the cups up with the balloon. What do you think is going to happen if I let go of the cup, Claire?" (p.29)

\section{Pitching and Putting Clearly}

Wragg and Brown (2001) state that 'pitching' refers to "estimating the right intellectual level of the people you are teaching, so that you neither bewilder nor patronise them" (p. 29) while "putting clearly' means "phrasing the question by using words and phrases that are appropriate to the individual pupil or group" (p. 30). For example, teachers can ask 'What is the etiology of dental caries?' to dental school students but change the question to the primary level students as 'Why do sweets rot your teeth?' (p. 31).

\section{Directing and Distributing}


Wragg and Brown (2001) state that directing questions by "name, gesture, head movement or facial expression" on all students rather than only focusing on the ones who are willing to answer is to prevent "chorus answer and lack of control" (p. 31).

"One method of distribution is to ask every pupil in the group in turn" (p. 31). Also, there is a 'correct' way in distributing question. Wragg and Brown (2001) state that in directing and distributing questions, teachers have to pay attention to students' body language to "identify those who wish to contribute, those who are not attending and those who are puzzled" (p. 32).

\section{Pausing and Pacing}

Tobin (1987) as cited in Wragg and Brown (2001, p. 32) explains that "pausing briefly after a question and after an answer encourages more pupils to answer, more of the pupils to provide longer answers and more questions from pupils." Also, "pauses act as signal for pace" (p. 32). He states "if you want pupils to think before giving their answer, then you need to give them the time to do so" (p.32). The example of those is "Why do you think that ... is the case? I'm not going to tell you the answer now, so think about it before tomorrow's lesson" (p. 32).

\section{Prompting and Probing}

"Prompts and probes are follow-up questions when the first answers are inadequate, or inappropriate. Prompts contain hints while probes require more precise or detailed answers" (Wragg and Brown, 2001, p. 33).

According to Wragg and Brown (2001), there are three ways of prompting namely "Rephrasing the question in different, or simpler, words that relate to pupil's knowledge and experience, asking simpler questions that lead back to the original question and providing an information and asking questions that help the pupil to recall the answer" (p. 33).

The example of prompting is "Think back to what we learned about ... so what is ... about?". Meanwhile, the examples of probing are:

- Can you give me an example of that?

- Why do you think that is true?

- Is there another view?

- What is the idea behind that?

- Can you tell me the difference between the two?

\section{Listening to Replies and Responding}

(Wragg and Brown, 2001, p. 33)

According to Wragg and Brown (2001), the four types of listening are:

Skim listening

: "This is little more than awareness that a pupil is talking and is often done when the answers seem irrelevant" (p. 34)

Survey listening : In order to know what the students talk about, "the listener filters out extraneous material and identifies the key points or misunderstandings of the pupil" (p. 34)

Search listening : :Active searching for specific information to an answer, or to a series of answers." (p. 34)

Study listening : : "A subtle blend of search and survey listening, which goes beyond the words that the pupils use to their underlying meaning and uncertainties." (p. 34)

Wragg and Brown (2001) explain that responding is what the teachers do after students answer or comment and it is done by showing enthusiasm, interest, etc. (p. 34). Below, Wragg and Brown (2001) listed the example of how teachers respond to students' answers and comment.

Answer/Comment

Ignored

Acknowledged

Repeated verbatim

Part of answer echoed
Teacher response

asks someone else, changes question, changes topic

nods, smiles, says 'right' or 'yes.'

merely re-states it, inflicts voice to convert into question

merely re-states acceptable part, inflects voice to convert into question 
Paraphrased Praise contribution

Corrected

Prompted

Probe paraphrases directly, sometimes in the form of a question

praises contribution, with elaboration

corrects incorrect part of answer, asks others to correct

asks prompting questions, or supplies direct hint to pupil

asks probing questions of pupil, or of other pupils

(Wragg and Brown, 2001, p. 35)

They also list three ways of showing interest which are "taking a pupil's answer or invite others to build on it, refering to a previous contribution and linking it to the present contribution, and incorporating the pupil's contributions (by name) into summaries of what has been learned" (p. 35)

\section{Sequencing}

Sequencing is "often the responding moves of the teacher in between questions." (Wragg and Brown, 2001, p. 36). Teacher can ask broader questions to narrower ones or narrower questions to broader ones, questions within the same types, a series of questions which leads back to the initial position and questions with relevant digressions. According to Taba (1971) as cited by Wragg and Brown (2001), extending and lifting mean teachers ask students questions that have the same level first and the higher level ones after. The teacher uses the random walk because of certain situations such as "poor planning, personal disorganization in the lesson or very distracting children." (Wragg and Brown, 2001, p. 36).

\section{METHODS}

The source of the data of this study is the transcripts of the two meetings from the audio recording while the data was the teacher's questions given to the students. I took all the questions asked by the teacher during the class meetings related to the lesson. In collecting the data, I used an audio recorder to record the teaching and learning in the classroom.

The subject of the observation is the teacher of Children 3A class. She is an alumnus of Petra Christian University majoring in English, and she continued her master's degree taking communication and media studies. She has been teaching for 6,5 years to both children and adults. She currently teaches the Children 3A class at Petra Language Center (PLC).

There were several steps applied in collecting the data. First of all, I tried to find out the information about the class and schedule of Children 3A class of Petra Language Centre (PLC). After that, I asked the Head of Petra Language Centre (PLC) for the permission to do the recording in Children 3A class for seven meetings in November 2016. I later submitted the approval letter from the Administration Office of English Department to the administrative staff of PLC.

After having all the permissions, I started to do the recording. In the first meeting; I met Ms. Bunga 30 minutes before the class to talk about the students and the class rules. I was told to sit behind the students and put the recorder on a chair near them so that the process of my data collection would not influence the teaching and learning process.

I did audio-recording to record the teaching and learning process in Children 3A class. One class session lasted for 60 minutes. The data includes the recording in a total of 240 minutes for four meetings. The data collection at PLC was done for four meetings out of 7 meetings starting from November $17^{\text {th }}$ until December $8^{\text {th, }}$ 2016. However, the recording for this study was done only on November 17th, 24th, 28th and December 8th. I was not able to do the observation on November $17^{\text {th }}$, December $1^{\text {st, }}$ and $5^{\text {th }}$ because of a personal matter and the Christmas celebration at Petra Language Center (PLC).

After collecting the data, I made the transcript of each meeting. The type of transcription that I chose is the detailed transcription. According to Zacharias (2012), detailed transcription means the focus is not only to the content but also how the narrative is conveyed. The transcript was made in September 2017. I decided to make the transcripts for only 2 meetings out of 4 meetings not only because in the fourth meeting the students had a small test but also because I only chose the meetings that have more questions asked by the teacher which means I would have more data for the analysis. The transcript would be very helpful for me to see the utterances produced by the teacher to make my data analysis 
easier. From the transcript, I can analyze which types of the question given and the questioning tactics used by the teacher. After making the transcripts, I marked the questions asked by teacher based on the types of questions and questioning tactics.

The analysis was based on the theory of Wragg and Brown (2001). I used the questions given by the teacher related to the materials discussed from the textbook during their English class meetings as my data.

Lastly, I made 2 tables to help me analyzing my data. I put the questions given by the teacher in the first column. I analyzed the questions and put a tick $(\checkmark)$ in the appropriate column or sub-column and matched the questioning tactics that are related to each type of question and wrote the total on the table.

\section{FINDINGS AND DISCUSSION}

This section presents about the types of question and questioning tactics used by the teacher of Children $3 \mathrm{~A}$ class. I provided the findings and then I also included the explanation of the examples related to the types of question and questioning tactics.

Types of Question Asked by the Teacher

From the classroom observation, I found out that the teacher of Children $3 A$ class only used two types of question in class according to Wragg and Brown (2001) namely conceptual and empirical question. The examples and explanations would be discussed below.

\section{Conceptual Question}

This is most asked type of question by the teacher of Children 3A class. Usually the teacher used this type of question to ask for definition and to help students in forming of a concept.

Example 1

(2.1.26) : Ada yang tau kaisar gak? (Does anybody know what kaisar is?)

(2.2.24) : Gak! (No!)

(2.1.27) : Gak ada yang tau kaisar itu apa hehe. Kaisar itu sama seperti raja (Nobody knows what an emperor is hehe. An emperor is the same as a king)

One of the elements of conceptual question is to ask for definition. From the example 1 above, the teacher asked about what kaisar (emperor) means by saying 'Does anybody know what 'kaisar' is?' which later she explained that an emperor is the same as the king since the students did not know what that is.

\section{Empirical Question}

This is another type of question that appeared in my data. This type of question requires student to recall facts and to make an observation. The examples are listed below.

Example 2

(1.1.72) : Uh-huh. Mereka tidak bisa - Terbang. Okay. Okay. Uh-huh. Penguin - coba lihat gak ada penguin terbang? (Uh-huh. They can't-fly. Okay. Okay. Uh-huh. Penguin - has anybody ever seen a penguin fly?)

(1.2.71) : Gak! (No!)

(1.2.72) : Gak ada! (No!)

Empirical question, like this one, requires student to recall facts. In example 2, the teacher asked this type of question to make students think of whether penguins do or can fly by asking 'Penguin - has anybody ever seen a penguin fly?'.

\section{Value Question}

Value question discusses more about environmental and social matter. However, I did not find any question related to this type of question in the data basically because this class focused mostly on language learning such as the vocabularies, grammar, tenses, etc.

Questioning Tactics Used by the Teacher

From the classroom observation, I found out the questioning tactics used by teacher of Children $3 \mathrm{~A}$ class according to Wragg and Brown (2001) which are structuring (signposting), directing and 
distributing, pausing and pacing, prompting and probing, listening to replies and responding and sequencing. The examples and explanations would be discussed below.

\section{Structuring (Signposting)}

The examples below were the questions asked by the teacher of Children $3 \mathrm{~A}$ class related to this questioning tactic found in the data.

Example 3

(2.1.1) : So, yesterday kita sudah latihan sampai - yaitu ini. Mengenai halaman berapa? Page berapa kemarin? What page? Page... page 41. On textbook. Nah, and also we have done excercises too, right? Kita juga sudah mengerjakan exercise yaitu di textbook page berapa kemarin? Sampai page? Textbook sampai page berapa? Uh - ah page 17. Hari ini kita mau lanjut lagi ya. Nih, sampai bacaan page 44 until page 45 . Kita mau bahas tentang reading. Reading yaitu judulnya apa? Siapa yang sudah - sudah ketemu belum? Imel? Page 44. Page 44. Can you find it, Imel? Okay, alright. The tittle is called the - apa? ( - what?) Together! The... the what? The whale and the penguin. Masih ingat whale itu apa? (Do you still remember what 'whale' is?)

(2.2.1) : Paus!

Example 3 shows that at the beginning of the second meeting, teacher mentioned the tittle of the reading passage which was 'the whale and the penguin'. Then, teacher asked the students if they still remembered what whale is by saying 'Do you still remember what 'whale'? is' which they have already learned about in the previous meeting since they were talking about the same animal in both meetings. When teacher asked 'do you still remember...', that means they already talked about it before and teacher was just checking if they still know what they have talked about. The purpose of asking questions as shown in example 5 and 6 is to simply review and talk about what they have discussed before moving on to the next topic or discussion.

\section{Pitching and Putting Clearly}

This tactic is used by teacher to ask question that is suitable for students' level of proficiency. However, there is no evidence in the data that shows the teacher ever using this questioning tactic. That is because teacher always asked questions that suit the students' level by asking them using easy and simple words used in daily life that helped them to understand the questions easier instead of difficult words and terms that they do not understand.

\section{Directing and Distributing}

By far, this is the questioning tactics that the teacher of Children $3 \mathrm{~A}$ class used the most. Teacher has to make sure everyone in the class has the opportunity to answer the questions. There are ways in directing and distributing question such as calling the name or making movements that point out a particular student to answer.

\section{Example 4}

(1.1.164) : Hu-uh. Good! Okay, sekarang (now) ...eh...Rosemary! Can you...eh...can you play...eh...football?

(1.2.171): Yes, I can

(1.1.165) : Okay, eh... Hayla! Do you live with you mother?

$(1.2 .172)$ : Yes, I can

(1.1.166) : Eh! Lho, do!

$(1.2 .173)$ : Yes, I do

(1.1.167) : Uh-huh. Okay, Joice! Can you draw an elephant?

$(1.2 .174)$ : Yes, I can

Example 4 is another example of how the teacher made sure her all of students got the chance to answer which is why she always asked her students questions in turns. After she called one of her students, Rosemary to answer the question, then she proceed to call other students by name, Hayla, Joice, etc so they knew it was their turn to answer.

\section{Pausing and Pacing}


After asking a question and after the students answer, teacher need to give students some time to think in order for the students just to think of the answer and to be able to give a more elaborate answer. It can be by giving a short pause or a chance for students to answer in the next meeting.

Example 5

(1.1.80) : Ya, Imel dulu. Imel dulu. Iya? Apa? (5) Apa itu artinya? (Ya, Imel first. Imel first. Iya? What? (5) What does it mean?

(1.2.80) : Senyum (Smile)

Example 5 above shows how the teacher gave some time for her student to think of the answer before asking the student again. After she asked the question to one of her students, there was (5) in the dialogue which means the she gave 5 seconds of pause before asking another question.

\section{Prompting and Probing}

Prompting means asking follow-up question when the first answer is inappropriate. Prompting means teacher provides hints while probing means teacher asks for more detailed answer. However, there is no use of prompting and probing tactics found in the data.

\section{Listening to Replies and Responding}

When the students answer a question, teacher has to listen to their replies with different types of listening which are skim listening, survey listening, search listening and study listening. Not only listening, teacher can also give responses after the students answer the questions.

After asking questions to her students, the teacher of Children 3A class often did survey listening which means she listened to her students' answer to find the key points from their answers. However, most of the time the teacher always asked questions that required short and simple answer so survey listening was done when the students gave a longer answers.

There are many ways of showing teacher's responses. However, there most common responses given by the teacher of Children $3 \mathrm{~A}$ class were acknowledged, repeated verbatim, corrected and prompted.

Example 6

(1.1.8) : Kalau can gak pake ' $t$ ', itu artinya? (What does can with no 't' mean?)

(1.2.7) : Bisa (Can)

(1.1.9) : Ya. Tapi kalo koma diatas ' $t$ ' berarti? (Ya. But what does coma with ' $t$ ' mean?)

(1.2.8) : Tidak bisa (Can't)

Example 6 above is just one of the many examples of how teacher acknowledged answers from students. It shows how the teacher acknowledged the student's answer by simply saying 'ya' after she asked what the word can with no ' $t$ ' mean and her student gave a correct answer.

\section{Sequencing}

This is related to what the teacher does after students answer a question. The ways of sequencing are (1) asking the same type of question, (2) asking the same level of question and the higher ones after (3) asking a narrow to a broader question and vice versa, (4) asking several questions that lead to the initial position, (5) asking questions with relevant digressions and (6) asking random questions

Example 7

(1.1.25) : Okay, terus kalo penguins apa sih bahasanya? (Okay, then what penguins mean in Bahasa?)

(1.2.24) : Penguin!

(1.1.26) : Kan sama penguin ya penguin. Tapi tinggalnya dimana Ice itu? (It is the same penguin is penguin. But where do they live? Ice?)

(1.2.25) : Es! (Ice!)

Example 7 above shows how the teacher used sequencing tactic to ask same level of question first then the higher one after. She first asked her students what penguins mean in Bahasa (Okay, then what penguins mean in Bahasa?), then she proceed to ask where do penguins live (But where do they live? Ice?).

4.3 Questioning Tactics Used Related to Each Type of Question

\begin{tabular}{|c|c|c|c|c|c|c|c|}
\hline & ST & PP & DD & PPa & PPr & LR & SQ \\
\hline CQ & 5 & 0 & 25 & 0 & 0 & 6 & 16 \\
\hline
\end{tabular}




\begin{tabular}{|c|l|l|l|l|l|l|l|}
\hline EQ & 0 & 0 & 1 & 0 & 0 & 1 & 3 \\
\hline VQ & 0 & 0 & 0 & 0 & 0 & 0 & 0 \\
\hline
\end{tabular}

From the table above, it shows that for conceptual question, the teacher used directing and distributing 25 times, sequencing 16 times, listening to replies and responding 6 times and structuring (signposting) 5 times. Meanwhile, for empirical question, the teacher only used sequencing tactic 3 times, directing and distributing once and listening to replies and responding also once. However, there are no tactics used by the teacher to ask value question since there are no value questions asked to the students.

The table shows the similarity of Conceptual and Empirical questions in which the tactics used for both types questions were almost the same except for no structuring tactic used in any Empirical question. Both Conceptual and Empirical questions use directing and distributing, listening to replies and responding and sequencing. Whereas the only difference is only in the total number of how many questioning tactics used related to Conceptual and Empirical question. There are more tactics used for Conceptual questions than the Empirical question which occurred because the teacher did not ask many Empirical question.

Lastly, the types of question given by the teacher that appeared in my data were the conceptual and empirical questions. The questioning tactics used were structuring. Finally, the overall conclusion of the study would be presented in chapter five.

\section{CONCLUSION}

I did this study to find out the types of questions and questioning tactics used by the teacher of Children 3A class at Petra Language Center (PLC). The theory was about questioning in primary school by Wragg and Brown (2001). The data were all the questions asked by the teacher during the class meetings related to the lesson.

The study was based on only one teacher, one class, and in two meetings. I chose the teacher of Children 3A class as my subject for my study. For the instrument, I used classroom observation.

From the study, I found out that the types of questions the teacher used in the classroom were only Conceptual Question and Empirical Question. The teacher of Children 3A class only focused on asking questions that require students to think of definition and facts or in other words, teacher tried to check students' understanding. Meanwhile, for the questioning tactics used, there were structuring, directing and distributing, pitching and putting clearly, pausing and pacing, listening to replies and responding and sequencing. Looking at the most used tactic which is directing and distributing, I concluded that teacher wanted to make sure every student understand the materials discussed in class by giving the opportunity to everyone to answer questions.

I concluded that the teacher of Children 3A class asked different types of question and used various questioning tactics to check students understanding by asking for the meanings and definitions since students are in beginner level. Teacher also tried to give equal opportunities to every students to answer questions by asking everyone in turns. I hope that there will be more studies conducted for higher level students and adults. This study hopefully would be able to help teachers to ask different types of question and use more questioning tactics in the classroom.

\section{REFERENCES}

Brock, C. A. (1986). The effect of referential question on ESL classroom discourse. TESOL Quarterly, 20, (1), 46-59.

Cameron, L. (2005). Teaching languages to young learners (8th ed.). Cambridge: Cambridge University Press.

Ellis, R. (1990). Instructed second language acquisition: Learning in the classroom. Oxford: Basil Blackwell Ltd.

Farahian, M. and Rezaee, M. (2012). A case study of an EFL teacher's type of questions: an investigation into classroom interaction. Procedia-Social and Behavioral Sciences, 47, 161-167. 
French, P. and Maclure, M. (1983) 'Teachers' questions and pupil answers: an investigation of questions and answers in the infant classroom', in Stubbs, M. and Hillier, H. (eds), Readings in Language, Schools and Classrooms, second edition, London: Methuen.

Gall, M. D. (1970). The Use of Questions in Teaching, Review of Educational Research, 40, 707-721.

Kramsch, C. J. (1986). From language proficiency to interactional competence. The Modern Language Journal, 70(4), 366-372.

Suryanti, N. (2015). Classroom Interaction Strategies Employed by English Teachers at Lower Secondary Schools. TEFLIN Journal, 26(2), 247-264. doi: http://dx.doi.org/10.15639/teflinjournal.v26i2

Wragg, E. C., \& Brown. (2001). Questioning in the Primary School. London: Leverhulme Primary Project Classroom Skills Series. London and New York

Wu, K. Y. (1993). Classroom interaction and teacher questions revisited. RELC Journal, 24(22), 49-68.

Zacharias, N. T. (2012) Qualitative research methods for second language education: A coursebook. Cambridge: Cambridge Scholars Publishing. 